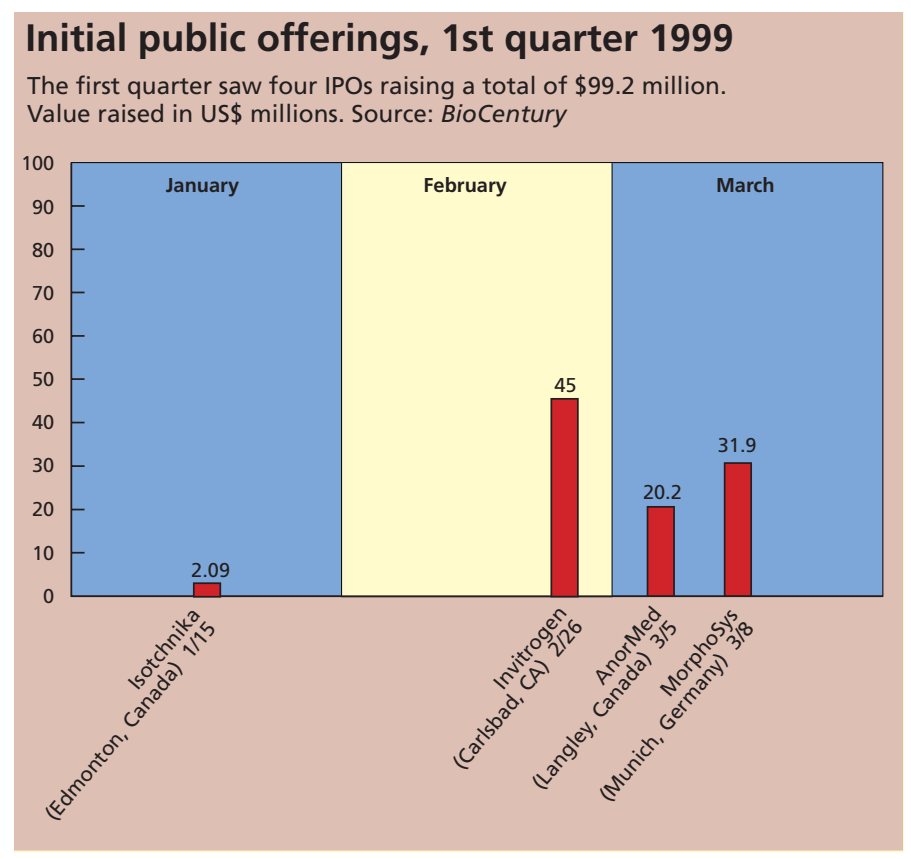

\section{Biopharmaceutical sector performance, 1st quarter 1999}

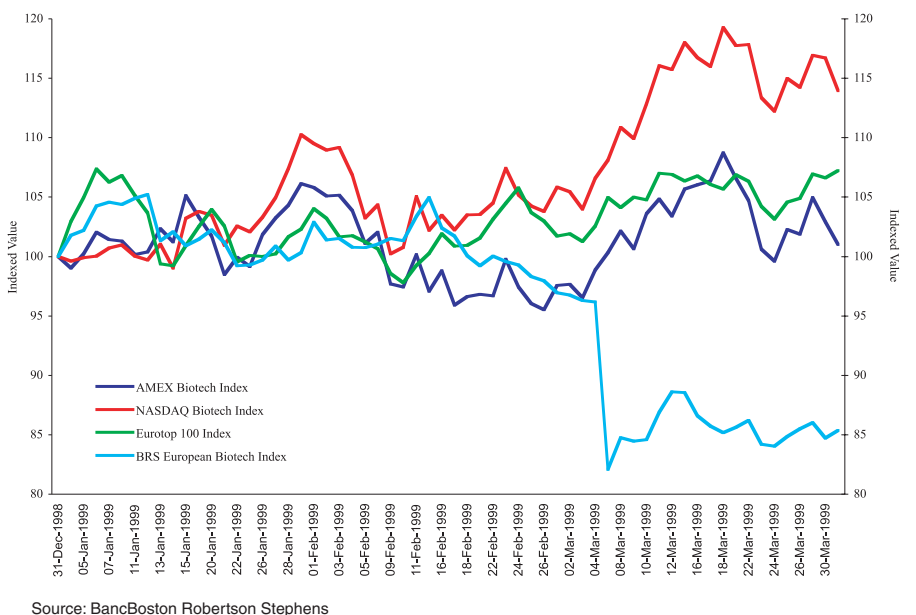

\section{New listings on European stock market}

Despite optimism for more biotechnology listings on European stock markets (Nature Biotechnol. 17, 211, 1999), there was only one such initial public offering (IPO) in the first quarter: combinatorial concern, MorphoSys (Munich, Germany), listed on the Neuer Markt on March 9, raising €25.8 million (US\$27.9 million). MorphoSys CFO Dave Lemus thinks the Neuer Markt is currently better for raising money in biotechnology than either the Nouveau Marché (Paris) or Easdaq (Brussels). Indeed, the drug delivery firm BioVector Therapeutics (Labege, France) had planned an IPO in February on the Nouveau Marché but postponed the listing for three to six months. "For the time being, there is no window" for biotechnology IPOs on the Nouveau Marché, says Emile Loria, BioVector's CEO. And Phytera (Worcester, MA), a US firm researching metabolic pathways in plants and microbes, postponed its Easdaq IPO in February. However, George Morris, analyst at Quartz Capital (London), puts this particular case down to the difficulties a US company has when trying to list in Europe (such as differences in the banking systems) rather than a problem with Easdaq itself.

\section{UK committee questions Cortecs}

A UK government Committee on Science and Technology hearing was held at the end of March to investigate who was to blame for misleading the stockmarket about the progress of Cortecs' (Cambridge, UK) lead products. In December 1998, Cortecs announced that its oral calcitonin osteoporosis drug, Macrotonin, and its Pseudostat vaccine were "not as advanced as had previously been indicated", and would therefore reach the market later than expected (Nature Biotechnol. 17, 12, 1999). The select committee grilled Philip Gould, formerly Cortecs' R\&D director but promoted to CEO following the incident, about whose responsibility it was to inform the board of the progress of therapies in clinical development. Initially, Gould said he was not a board member at the time and therefore could not comment. But under cross-examination he admitted that the CSO had ultimate responsibility. The CSO at the time was Michael Flynn, who subsequently resigned. On questioning, Flynn denied withholding information and said he still believes his original estimates to be accurate. In his view, which Gould shared, only a "new interpretation" by Gould of the data had led to the revised time-scales. As Flynn did not agree with the new interpretation he resigned. The committee has yet to decide whether legal action will be taken.
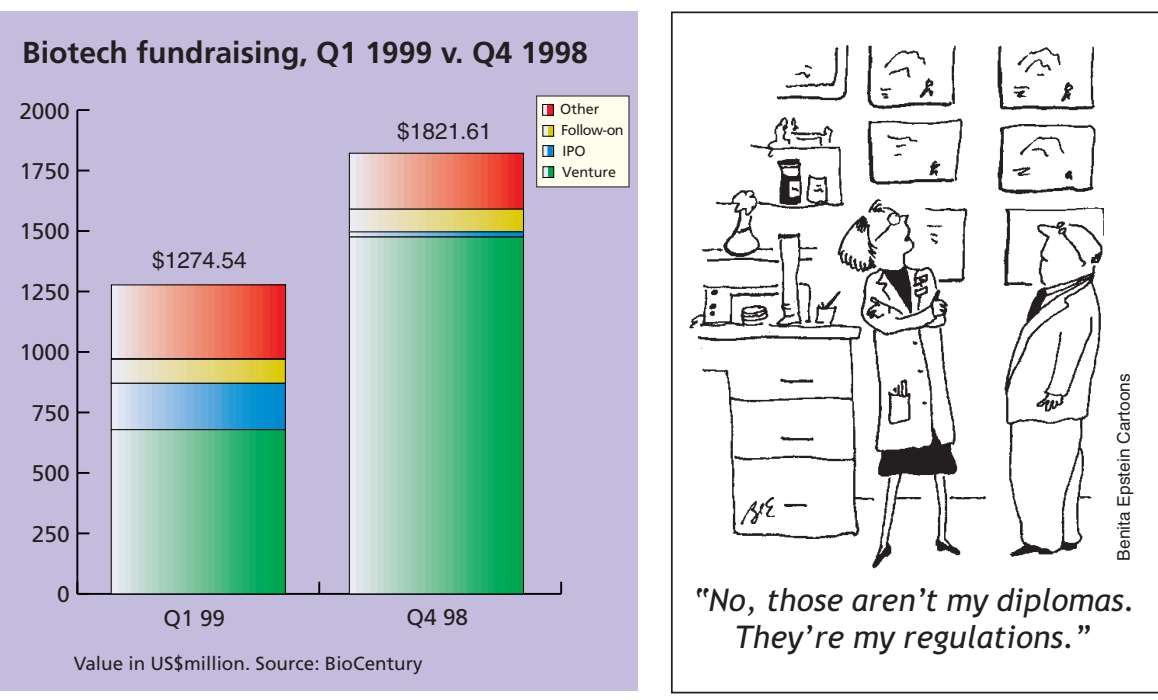

Top GMO patent application holders.

\begin{tabular}{lc}
\hline Institution & $\begin{array}{c}\text { No. of patent } \\
\text { applications }\end{array}$ \\
\hline Pioneer Hi-Bred Intl. (US) & 68 \\
Monsanto (US) & 62 \\
Calgene (US) & 49 \\
Zeneca (UK) & 45 \\
Novartis (Switzerland) & 42 \\
DuPont (US) & 36 \\
Plant Genetic Systems (Belgium) & 36 \\
ICl (UK) & 35 \\
University of California (US) & 30 \\
Cornell Research Found. (US) & 28 \\
Mycogen (US) & 26 \\
Mogen (The Netherlands) & 23 \\
\hline
\end{tabular}

Source: Derwent (London). GMO, genetically modified organism. 